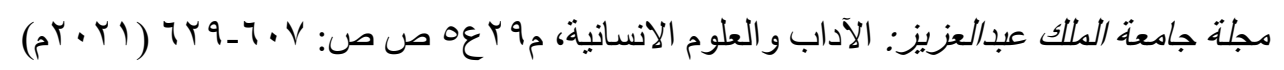

DOI:10.4197/Art.29-5.20

\title{
السمات الشخصية وعلاقتها بأساليب مواجهة الضغوط لدى طالبات ك5 لية التربية في جامعة حائل
}

\author{
كوثر سلامة جبارة

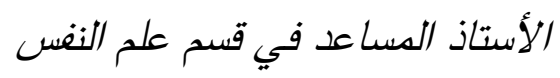 \\ كلية التربية - جامعة حائل
}

مستخلص. هدفت الدراسة الحالية إلى التعرف إلى مستوى السمات الثخصية لاى طالبات كلية التربية في جامعة

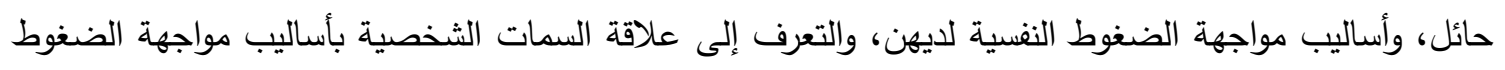

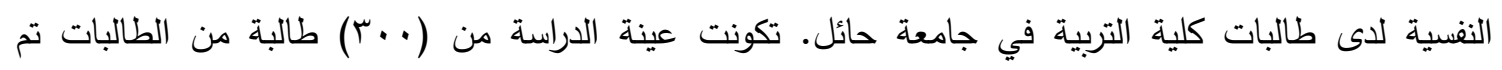

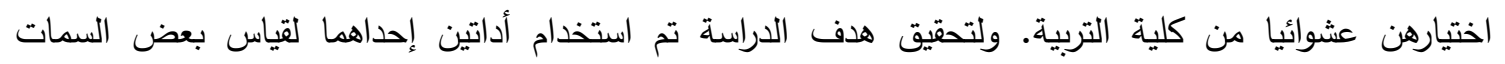

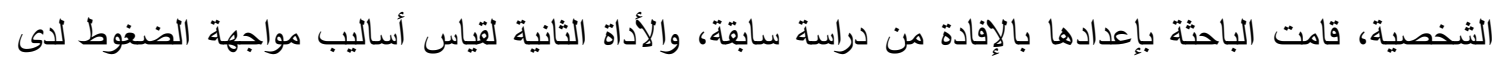

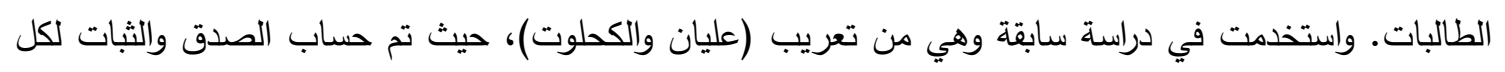

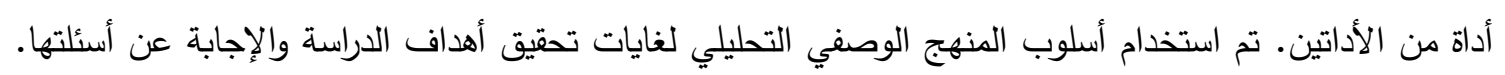

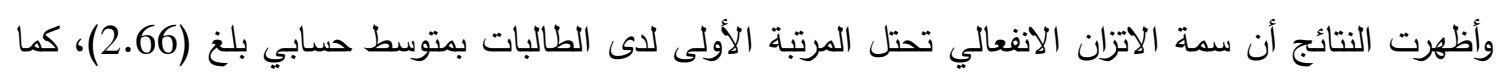

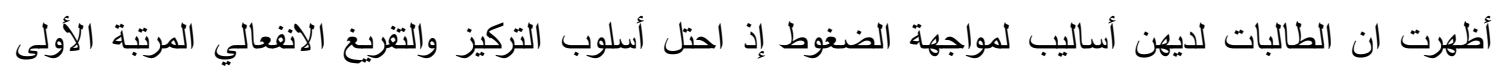

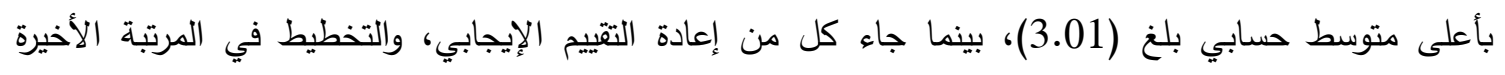

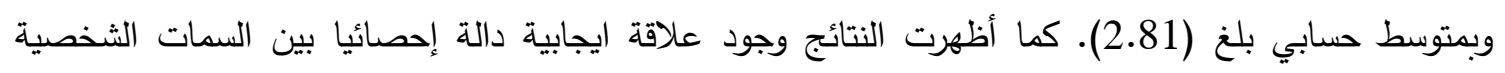

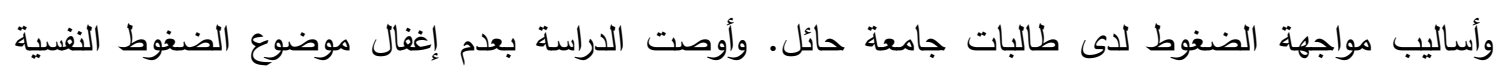

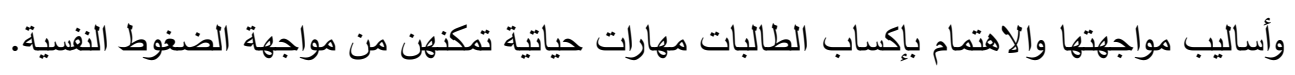

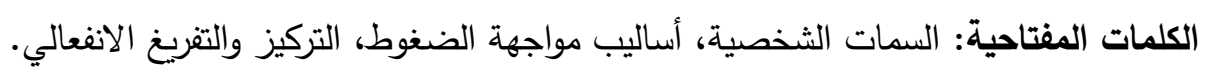

لتحقيق الازدهار الاقتصادي والتطور الفيعي الحضاري

المقدمة

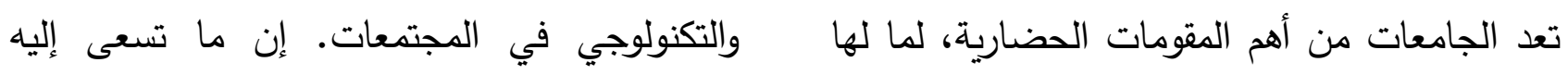

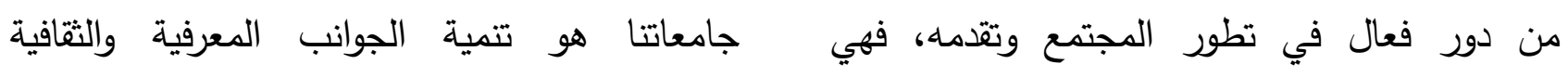

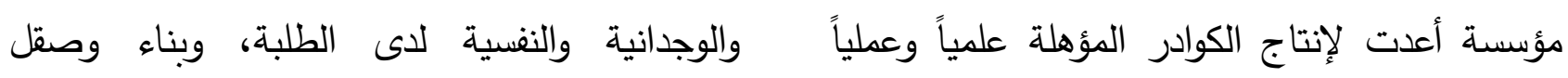


حياته اليوميّة في المنزل والعمل والثّارع، وتتراكم فوق بعضها البعض لتسبّب حالةً من الانفجار

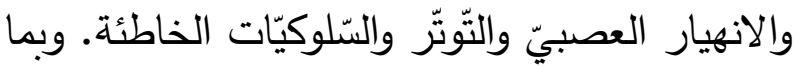
أن السمات الثخصية مهمة في نمو الطلبة نمواً نفسياً سوياً قد يعكس أثره على مواجهة الضغوط والذي يختلف بطبيعة الحال من شخصية لأخرى، لهبل فلكل شخصية سماتها المميزة والتي تحدد خصائص من فئه هذه الثخصية ونقاط ضعفها وقوتها، وأيضا مدى مرونتها وقدرتها على التكيف، من هنا نشأت فكرة الدراسة الحالية، وهي التعرف إلى بعض سمات الثخصية لدى عينة من طالبات المرحلة الجامعية في جامعة حائل وعلاقتها بأساليب مواجهة الضغوط إن طبيعة الأشخاص تختلف في الأقوال والتصرفات وفي السلوك والانفعال الصادر عنهم، رغم أنهم يتثابهون في عدة نواح، إلا أن هنالك خصائص تميزهم عن بعضهم البعض، وأنماط سلوكية خاصة تحدد الطريقة المنفردة في تكيفهر مع البيئة، أي أن لكل فرد شخصيته المستقلة والمميزة، فالثخصية تعتبر من المراجع الهامة في علم النفس الحديث، إذ اهتم كثير من علماء النفس بدراستها ومحاولة وضع أسس نظرية لها والقيام بتفسير السلوك الانساني في إطار منطقي منظم، وبالرغم من تعدد الدراسات والبحوث التي تتاولت الثخصية، الا أن هذا التنظيم لا يزال مثيرا للجدل ويعمه الغوض. يعتبر مفهم الشخصية من أكثر مفاهيم علم النفس لهان تعقيدا، فهو يشمل كافة الصفات والخصائص
شخصية الطلبة لتمكنهم من التكيف داخل مجتمع الجامعة، والتكيف والتعايش داخل المجتمع الذي يعيشون فيه، ومن ثم تأدية دورهم الاجتماعي

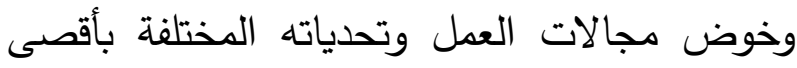
فاعلية ممكنة. تتحمل الجامعة مسؤولية مساعدة الطلبة على مواجهة تلك التحديات، وتذليل الصعوبات التي تواجههم من خلال توفير الخدمات الأكاديمية المتخصصة التي تعنى بتقديم البرامج

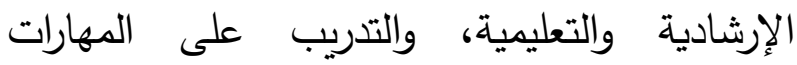
الدراسية المعينة على النجاح والتفوق مثل مهارات استخدام المكتبة ومصادر التعلم، ومهارات البحث العلمي، ومهارات القراءة والاستماع وتدوين الملحوظات، إضافة إلى مهارات تطوير الذات والمهارات الشخصية مثل تنظيم الوقت، والاتصال

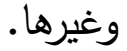

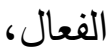
وتعد الضغوط النفسية من أكثر الظواهر انتشارا ولا يستطيع الفرد الهروب منها، بالتالي يجب عليه مواجهة تلك الظروف والسيطرة والتغلب عليها، من خلال التسلح وتعلم واكتساب مهارات واستراتيجيات لمواجهتها، وجعل الفرد في حالة توازن. ويختلف

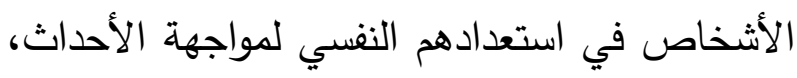

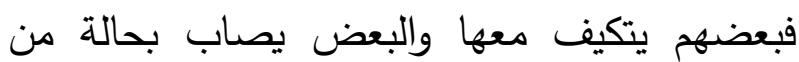
الإحباط والقلق والمعاناة.

وفي ظل الاهتمام بالصحة النفية للطلبة وما يتعرض له الطالب اليوم من ضغوط، وما يستجد من

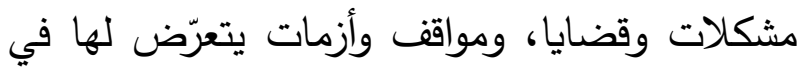


في المواقف الاجتماعية؛ لأن سلوك الفرد هو انعكاس لشخصيته وعلى هذا الأساس يتمثل الموقف الاجتماعي في مجموعة العوامل أو المحددات الخارجية لسلوك الفرد وما يحمله من تصورات داخلية تتعكس على سلوكه من حيث درجة البساطة والتعقيد في طريقة التعامل، وان كل ما يصدر عن الانسان من سلوك له دلالة ومعنى حتى وإن صعب فهمه أو معرفته، ويرجع ذلك إلى السمات المميزة لشخصية الفرد والتي تعبر عن نفسها ضمن معطيات الموقف الخاص. (أمارة، ج . . ؟). ثانيا: السمات الشخصية: انشغل الإنسان منذ قديم الأزل بمحاولات فهم ذاته ومعرفه صفات وسمات شخصيته، كما اهتم الناس أيضاً بمعرفه طبيعة السمات وصفات الشخصيات التي يتعاملون معها، ومعرفه كيف تتصرف تلك الشخصيات في المواقف المختلفة. ولقد توصلت الدراسات إلى العديد من الأساليب والطرق العلمية لمعرفه هذه السمات وطباع الشخصية ومدى تكونها والتي تشكل سلوك الفرد الناتج من تفاعلات المكونات النفية والاجتماعية والانفعالية . يعرف (Cattel) السمة بأنها: "مجموعة ردود الأفعال والاستجابات التي يربطها نوع من الوحدة، التي تسمح لهذه الاستجابات أن توضع تحت اسم واحد، ومعالجتها بالطريقة نفسها في معظم الأحوال، بينما يعرفها ألبورت بأنها نظام عصبي مركزي عام يتميز به الفرد، ويعمل على جعل المثيرات المتعددة
الجسمية والعقلية والوجدانية، في تفاعلها وفي تكاملها مع الفرد ومحيطه. ولهذا تعددت وتباينت الآراء التي تعالج مفهوم الشخصية وطبيعتها وخصائصها، ويحمل تعبير الثخصية معان متعددة فهو مفهوم معقد ومتغير ، فقد اختلفت وجهات نظر علماء النفس وتتوعت تقنيراتهم وطرق وأساليب دراستهم للشخصية. أولا: تعريف الثخصية: تعتبر الشخصية وسماتها من المحاور المهمة جداً في علم النفس وقد عرفها أحمد عبد الخالق

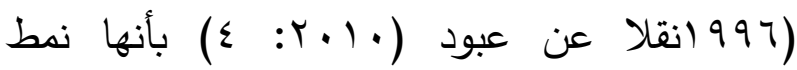
سلوكي مركب وثابت ودائم إلى حد كبير ، يميز الفرد عن غيرة من الناس، ويتكون من تتظيم فريد لمجموعة من الوظائف والسمات والأجهزة المتفاعلة معاً، والتي تضم القدرات العقلية والوجدان أو الانفعال والإرادة وتركيب والوظائف الفسيولوجية والتي تحدد طريقة الفرد الخاصة في الاستجابة وأسلوبه الفريد في التوافق مع البيئة.

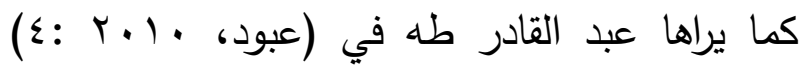
بأنها: التنظيم الدينامي لسمات وخصائص ودوافع الفرد النفسية والفسيولوجية والجسمية، ذلك التنظيم الذي يكفل للفرد توافقه وحياته في المجتمع. ولكل شخص تتظيمه هذا الذي يميزه عن غيره، أي لكل شخص في المجتمع شخصيته الفريدة. ولا بد من الإشارة إلى الصلة الوثيقة بين علم نفس الشخصية وعلم النفس الاجتماعي بدراسة سلوك الفرد 
الضغط النفسي:

ويستخدم مصطلح الضغوط النفسية للدلالة على نطاق واسع من حالات الانسان الناشئة كرد فعل لتأثيرات مختلفة بالغة القوة. وتحدث نتيجة العوامل الخارجية مثل كثرة المعلومات التي تؤدي إلى إجهاد انفعالي. وتظهر نتيجة التهديد والخطر • (عثمان،

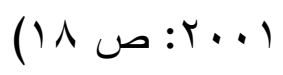
ويرى Hill هيل المذكور في (الطراونة، . . . ب)، أن الضغط النفسي حادثة تولا أزمة عند الفرد الذي ليس لديه الاستعداد الكامل للتعامل معها، أو قد تكون

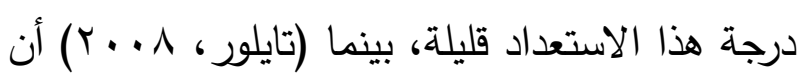
الضغط خبرة انفعالية سلبية، يترافق ظهوره مع حدوث تغيرات بيو كيميائية، وفسيولوجية ومعرفية، وسلوكية يمكن التتبؤ بها، ويمكن أن تؤدي إما إلى لى تغيير الحدث الضاغط، أو إلى التكيف مع آثاره. أما الرائد في استخدام المصطلح في علم النفس فهو العالم هانز سيلي "Selye" حيث كان متأثراً بفكرة أن الكائنات البشرية يكون لها رد فعل للضغوط عن طريق تتمية أعراض غير نوعية. وذكر أن الضغوط يكون لها دور هام في إحداث معدل عال من الإنهاك والانفعال الذي يصيب الجسم، إذ أن أي إصابة جسمية أو حالة انفعالية غير سارة كالقلق والإحباط والتعب أو الألم لها علاقة بتلك الضغوط. أما الرائد في استخدام المصطلح في علم النفس فهو العالم هانز سيلي "Selye" حيث كان متأثراً بفكرة أن الكائنات البشرية يكون لها رد فعل للضغوط عن
متساوية وظيفيا، كما يعمل على إصدار وتوجيه أشكال متساوية من السلوك التكيفي والتعبيري.

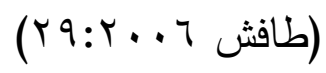
ثالثا: الضغوط النفسية: اختلفت وجهات النظر في إعطاء معنى لمفهوم الضغوط فكل منظر أو باحث يرى فيه موقفا معينا ومن ثم يفصل مفهومه، ومضمونه، أنواعه ومصادره وأساليب مواجهته وفق الهدف أو الدراسة التي هو بصددها. لذا نجد من يرى أن الضغوط تشير إلى "درجة استجابة الغرد للأحداث والمتغيرات المحيطة، في حياته اليومية مؤلمة كانت أم سارة، تلك الأحداث التي ترتبط ببعض التغيرات الفسيولوجية في الوظيفة البنائية لجسمه". (أمارة، 990 1: 109 وتعد الضغوط أحد المظاهر الرئيسية في حياتتا المعاصرة، وما هي إلا ردة فعل للتغيرات التي طرأت على كافة أنواع الحياة، والأفراد في هذا العصر يعانون من ألوان مختلفة من الاضطرابات النفية على رأسها القلق والاكتئاب نتيجة لما يتعرضون لله من ضغوط وما يهدد حياتهم ومستقبلهم من أخطار . يتعامل الأشخاص مع الضغوط والمواقف الصعبة من خلال أساليب متعددة لخلق حالة من التوازن

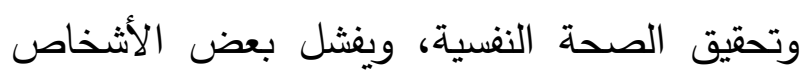
في ذلك، وقد يرجع ذلك إلى اختلاف المواقف وكذلك بك اختلاف شخصياتهم وسماتهم الشخصية التي يتميزون بها. 
المتلاحقة من تطور وتقدم هائل، لا يستطيع مواكبتها وملاحقتها، فيشعر بالحجز والإحباط، ويعيش في صراع بين ما هو فيه وبين ما يحدث حوله من بناهن مواقف ضاغطة نتيجة لمشكلات شخصية أو أسرية ومدرسية وأكاديمية ومهنية تتضمن أحداثا قد تنطوي على الكثير من التوتر والقلق في شتى ومانه مجالات

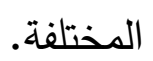

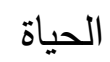
وهناك العديد من الأساليب الخاصة بالضغوط، حيث أنه قد تكون تلك الضغوط نابعة من مشكلات

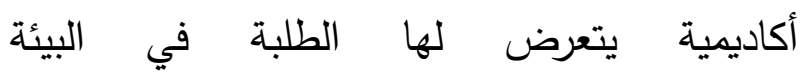

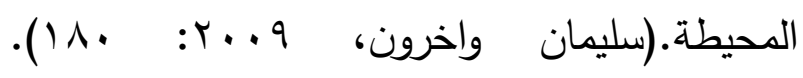
رابعا-أساليب مواجهة الضغوط:

ويعرف "علي" أساليب مواجهة الضغوط بأنها "الأساليب التي يواجه بها الفرد أحداث الحياة اليومية

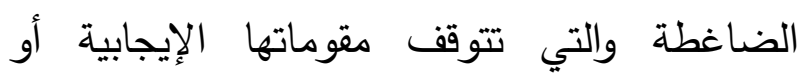

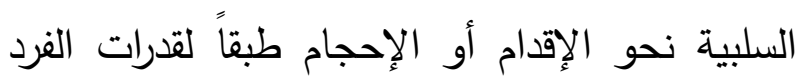

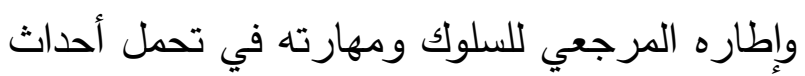
الحياة اليومية الضاغطة وطبقاً لاستجاباته: التكيفية نحو مواجهة هذه الأحداث دون إحداث أية آثار

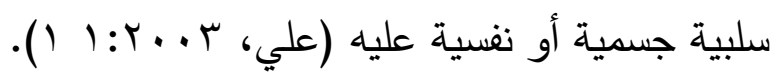
هناك طرق عديدة للتوافق مع الضغوط بدنيا ونفسيا،

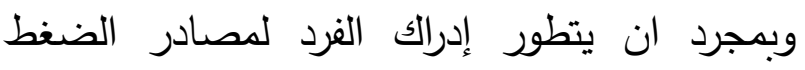
العصبي وكيف أنه يؤثر عليه شخصيا، سيتمكن من إن لتراك تنفيذ خطوات إيجابية لإدارة هذه الضغوط. وقد ميز البعض بين أسلوبين من أساليب مواجهة الضغوط:
طريق تتمية أعراض غير نوعية. وذكر أن الضغوط يكون لها دور هام في إحداث معدل عال من الإنهاك والانفعال الذي يصيب الجسم، إذ أن أي

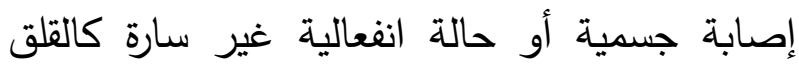
والإحباط والتعب أو الألم لها علاقة بتلك الضغوط. ويعرف سلي Selye" " الضغط النفسي بأنه: الاستجابة غير المحددة الصادرة من الإنسان لأي مثير أو طلب يوجه نحوه”.

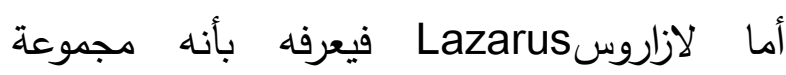
المثيرات التي يتعرض لها الفرد بالإضافة إلى دانى الاستجابات المترتبة عليها وكذلك تقدير الفرد

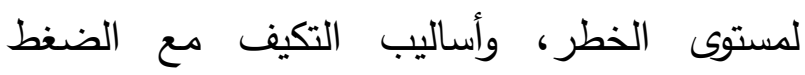
والدفاعات النفسية التي يستخدمها الفرد في مثل هذه

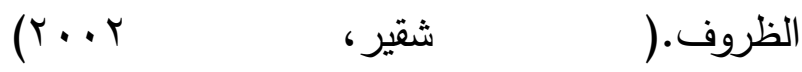

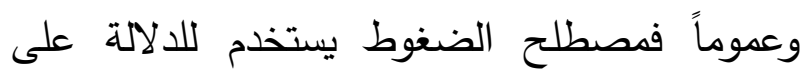
نطاق واسع من حالات الإنسان الناشئة كرد فعل لتأثيرات مختلفة القوة، وتحدث الضات الضغوط نتيجة الضئة العوامل الخارجية، مثل كثرة المعلومات التي تؤدي إلى إجهاد انفعالي، وتظهر الضغوط نتيجة التهديد والخطر ، وتؤدي الضغوط إلى تغيرات في العمليات

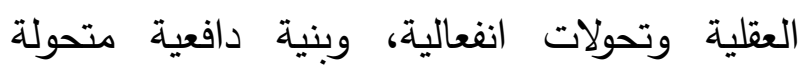
للنشاط، وسلوك لفظي وحركي قاصر .

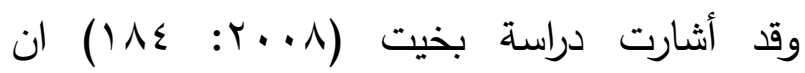
الانسان في القرن الحالي يتعرض لسلسلة طويلة من دن مشكلات الحياة الضاغطة يمر بها يوميا نتيجة لضغوط شتى تلاحقه بسبب التغيرات السريعة 
الشخصية وأساليب مواجهة الضغوط. وهنا تظهر وظيفة أساليب المواجهة حيث تمثل الحماية من آثار الضغوط بإزالتها أو تعديلها أو جعل النتائج الانفعالية للموقف في إطار يمكن السيطرة عليه وإدراك الظروف الضاغطة بشكل يعين على إضفاء الطبيعة المحايدة للوقف، وخفض خصائصه المزعجة.

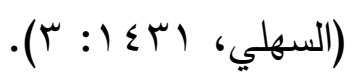

مثكلة البحث:

من خلال عمل الباحثة في التدريس في هذه المرحلة، وإيمانها بأن مرحلة التعليم الجامعي من أهم المراحل التعليمية في حياة الطالب، لذا فهي جديرة بالعناية والاهتمام المستمرين في كافة مستوياتها المختلفة، خاصة وأن المرحلة العمرية لطلبة الجامعة تمتلك طاقات وإمكانيات غير محدودة من العطاء والبذل والتي تمكنهم من التقدم نحو المواقع المتقدمة في المجالات المختلفة. من هذا المنطلق لا بد من التعرف على مستوى بعض السمات الثخصية التي تتوفر بمستوى معين لدى طلبة الجامعات؛ ليتمكنوا من مواجهة التحديات الأكاديمية والاجتماعية؛ لتمكنهم من مواصلة تعليمهح بنجاح. وهناك دراسات قليلة تطرقت إلى دراسة السمات الشخصية والضغوط النفسية مثل دراسة (القائدي، Y ا • (Y)، ولكن لا يوجد في - حدود علم الباحثة - دراسة تناولت السمات الشخصية لدى طالبات كلية التربية في جامعة حائل وعلاقتها بأساليب مواجهة الضغوط، لذا تعتبر هذه الدراسة الأولى من نوعها في - حدود علم الباحثة -
1- الاستراتيجيات الانفعالية في المواجهة: وفيها يلجأ الفرد إلى استخدام ردود الأفعال الانفعالية في مواجهة الضغوط مثل: التوتر ، والغضب، والإزعاج. r- الاستراتيجيات المعرفية في المواجهة: وفيها يلجأ الفرد إلى إعادة التفسير الإيجابي والتحليل المنطقي وبعض أنماط التفكير والنشاط التخيلي. وهنالك بعض الاستراتيجيات المعرفية لمواجهة ضغوط الحياة تتضمن التفكير العقلاني، والتخيل، والإنكار، وحل المشكلة، والفكاهة، والرجوع إلى الدين( الكفوري، . . . ب: 7 • ( ).

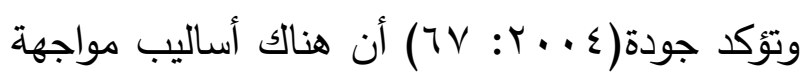
تعد كعوامل مساعدة تمكن الفرد من التصدي للضغوط النفسية وبالتالي توفر له الاحتفاظ بالصحة النفسية. ويستخدم الأفراد أساليب ووسائل متعددة للتغلب على أحداث الحياة الضاغطة والصعبة تساعدهم على التوافق مع هذه الأحداث والحفاظ على الاتزان الانفعالي والسلامة النفسية، مع تصور إيجابي

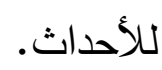
ويعود تباين الأفراد في استخدام هذه الوسائل إلى عدة عوامل منها نمط شخصيتهخ ومستوى قدراتهم وخبراتهم السابقة وطريقة تقييمهم لهذه الأحداث ومستوى ما يتمتعون به من صحة نفسية (جودة، . (TVO: : . . E وكما ذكر (السهلي، اسبء (1) أشارت نتائج بعض الدراسات إلى وجود علاقة بين بعض السمات 
- قلة الدراسات التي ت تاولت انب السمات الشخصية، وكذلك أساليب التعامل مع الضغوط. - إثراء الجانب النظري في هذا المجال. ثانيا: الأهمية العملية: - الاهتمام بجانب السمات الشخصية وأساليب مواجهة الضغوط لدى الطلبة. - تقديم المساعدة للقائمين على الطلبة في الجامعات للتعرف على الشخصية وواقع أساليب مواجهة الضغوط. - فتح آفاق جديدة أمام الباحثين لإجراء المزيد من الدراسات حول الموضوع وكذلك تتاول متغيرات أخرى قد يكون لها أثر بالموضوع.

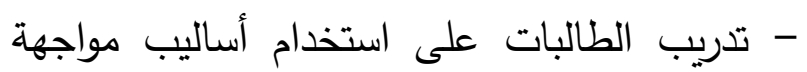
الضغوط النفسية. مصطاح الدراسة: الشخصية: هي تتظيم ديناميكي داخل الفرد للأجهزة النفسية والجسمية التي تحدد خصائص سلوكه وفكره إزاء المواقف المختلفة.

التعريف الإجرائي للشخصية: الصفات التي تميز الفرد من الاخرين نفسيا وجسميا وعقليا و انفعاليا واجتماعيا.

السمات الشخصية: السمات هي الخصائص التي تسمح لنا بمقارنة شخص ما مع الآخرين، أو هي الخصائص الفربدة المميزة للشخص، وقد تكون السمات وراثية أو مكتسبة، معرفية أو انفعالية أو متعلقة بمواقف اجتماعية.
والتي ستتناول شريحة ممن يدرس في هذه المرحلة المهمة. وأثارت مشكلة البحث التساؤلات التالية: 1- ما مستوى السمات الشخصية لدى طالبات كلية التربية في جامعة حائل؟

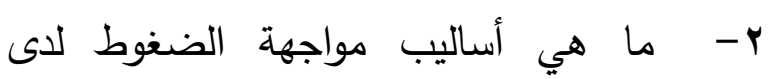
طالبات كلية التربية في جامعة حائل؟ r- ما العلافة بين السمات الشخصية وأساليب مواجهة الضغوط لدى طالبات كلية التربية في جامعة حائل؟

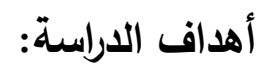
ا- التعرف إلى مستوى السمات الشخصية لدى طالبات كلية التربية في جامعة حائل. r- التعرف إلى أساليب مواجهة الضغوط لدى طالبات كلية التربية في جامعة حائل. r- التعرف إذا كان هناك علافة بين السمات الشخصية وأساليب مواجهة الضغوط لدى طالبات كلية التربية في جامعة حائل. أهمية الاراسة: تستمد هذه الدراسة أهميتها من أهمية الموضوع الذي تقوم بتناوله من حيث الوقوف على مستوى السمات الشخصية وأساليب مواجهة الضغوط، ومدى إسهام نتائجها وتأثيرها في القائمين على التعليم الجامعي ومتخذي القرار في جامعة حائل. أولا: الأهمية النظرية: تأتي أهمية هذه الدراسة النظرية من خلال: 


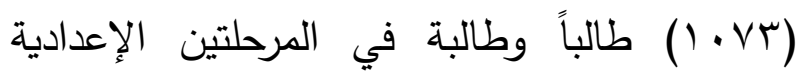

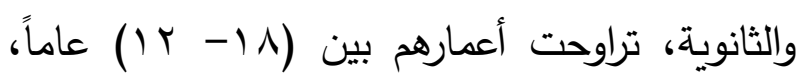
توصلت الدراسة إلى عدد من النتائج أهمها: أن

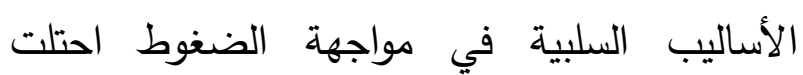
المراكز الأولى في الترتيب العام لأساليب مواجهة الضغوط (الإنكار، الاستسلام، التتفيس الانفعالي)، كما كثفت النتائج عن وجود فروق دالة إحصائياً بين عينتي الطلاب والطالبات على ثمانية أساليب للمواجهة، كذلك وجود فروق دالة إحصائياً بين

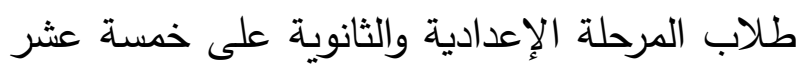
أسلوباً من أساليب المواجهة.

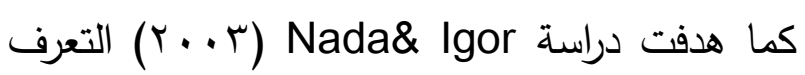
على العلاقة بين السمات الشخصية وأحداث الحياة الضاغطة وأساليب المواجهة في مرحلة المراهقة

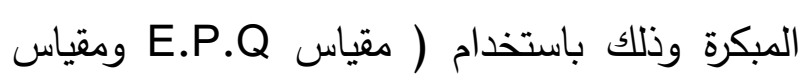

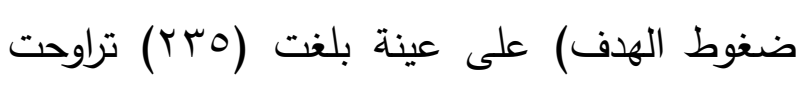

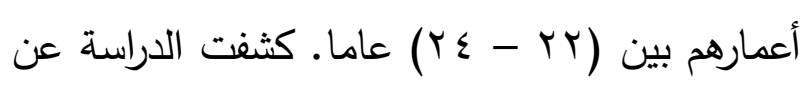
التأثير الايجابي للانبساط في مواجهة المشكلة وأسلوب مواجهة الانفعال. وهدفت دراسة (Hunt \& Evans,2004) إلى مواجل الانفعال. معرفة الفروق بين الجنسين في الذكاء الانفعالي

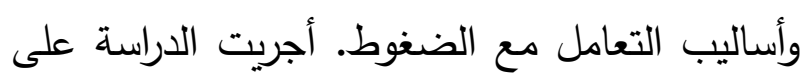

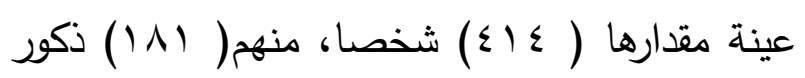
و) (YTr إناث، متوسط أعمارهم بr سنة. أظهرت نتائج الدراسة وجود علاقة ارتباطية دالة بين الذكاء الانفعالي وأساليب التعامل مع الضغوط.
التعريف الإجرائي للسمات الثخصية: الدرجة التي تحصل عليها الطالبة في المقياس الفرعي والذي تم تطبيقه في الدراسة وتتضمن سمات الاتزان. الضغوط النفسية: الاستجابة غير المحددة الصادرة من الإنسان لأي مثير أو طلب يوجه نحوه.

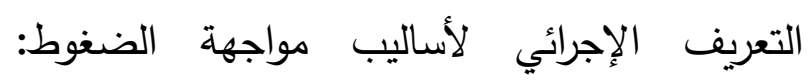

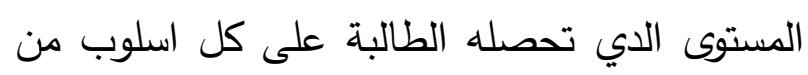
اساليب مواجهه الضغوط النفسية المتضمنة في القياس المطبق في الدراسة. حدود الدراسة: الحدود المكانية: اقتصرت هذه الدراسة على عينة من طالبات كلية التربية في جامعة حائل. الحدود الزمانية: تم تطبيق الأدوات على عينة من طالبات كلية التربية المسجلات في الفصل الدراسي الأول للعام

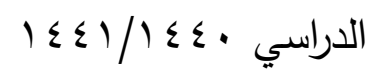
الحدود الموضوعية: اقتصرت الدراسة على معرفة مستوى السمات الثخصية ومستوى أساليب مواجهة الضغوط والبحث في العلاقة الارتباطية بينهما الاراسات السابقة: هدفت دراسة عبد الله (Y. . . إ) إلى التعرف على أساليب مواجهة الضغوط لدى طلاب المرحلتين الإعدادية والثانوية، وذلك باستخدام (مقياس أساليب

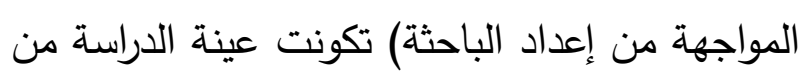


كما كثفت الدراسة عن وجود علاقة بين الجنس

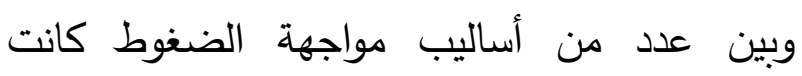

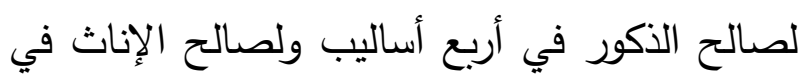
ثلاثة أساليب.

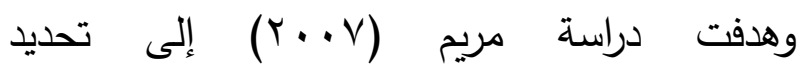
الاستراتيجيات التي يستخدمها الطلبة للتعامل مع درسه

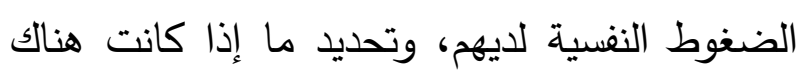

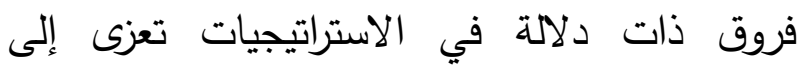
متغيرات: الجنس، السنة الأولى والرابعة، تكونت

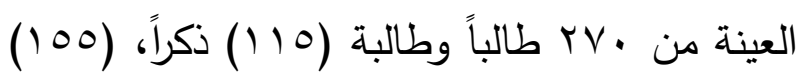

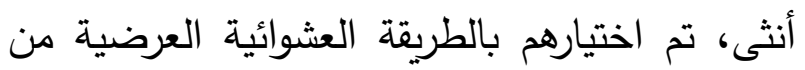
كلية التربية. طبقت الباحثة مقياس أساليب التعامل

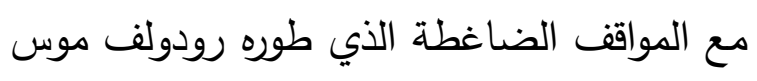
Rudolf H. Moss الدراسة إلى ميل الطلبة إلى استخدام الاستراتيجيات

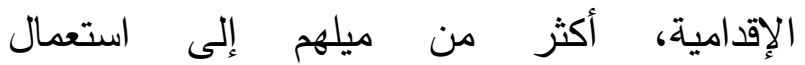
الاستراتيجيات الإحجامية. كما أشارت وجود فروق دالة إحصائياً بين الذكور والإناث في استخدام الإندات وجنات استراتيجية البحث عن المعلومات والإثابات المكافآت البديلة لصالح الذكور، وفي استخدام استراتيجية التتفيس الانفعالي وذلك لصالح الإناث. كذلك وجود فروق دالة إحصائياً بين طلبة السنة الأولى وطلبة الاندات السنة الرابعة في استخدام استراتيجيات: التحليل المنطقي، إعادة التقييم الإيجابي لصالح طلبة السنة

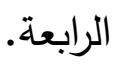

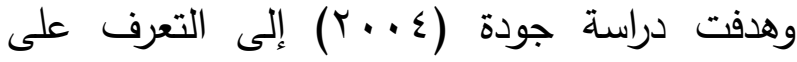
العلاقة بين أساليب مواجهة الضغوط النفسية والصحة النفية لاى طلاب جامعة الأقصى ومعرفة

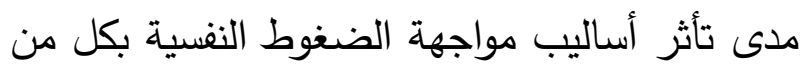
الجنس والتخصص ومكان السكن، وبلغت عينة

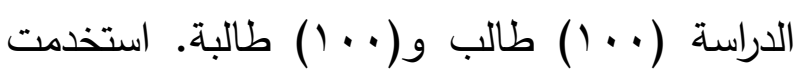
الباحثة في الدراسة مقياسين أحدهما لقياس أساليب مواجهة الضغوط والآخر لقياس الصحة النفسية. أظهرت نتائج الدراسة أن طلاب جامعة الأقصى يستخدمون أساليب متعددة في مواجهة أحداث الحياة

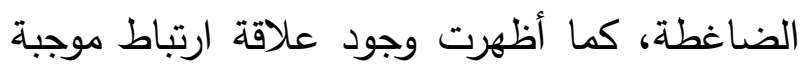
دالة بين أساليب المواجهة الفعالة والصحة النفسية، كذلك أظهرت عدم وجود فروق دالة في متوسطات درجات أفراد العينة في أبعاد أساليب مواجهة أحداث الحياة الضاغطة تعزى لمتغير الجنس

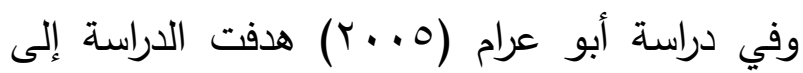
التعرف على أساليب مواجهة، الضغوط وعلاقتها ببعض سمات الشخصية لدى طلاب المرحلة الثانوية. تكونت عينة الدراسة من (عrع) طالبا و(乏OV) طالبة. استخدمت الدراسة (مقياس سمات الثخصية من إعداد الباحثة)، ومقياس أساليب المواجهة من إعداد منى عبد الله ب. ... كن. كانت نتائج الدراسة أن أهم الأساليب التي يعتمد عليها الطلاب هي اللجوء إلى الله، كذلك وجود علاقة بين طبيعة المدارس التابع لها الطلاب وبين أسلوبين من إلى لهن أساليب مواجهة الضغوط وهي لوم الذات والإنكار. 
استخدام الأساليب السلبية تعزى لمتغير المؤهل العلمي. كما أظهرت وجود فروق في استخدام الأساليب الإيجابية لصالح الخبرة الأكثر من عشر فري

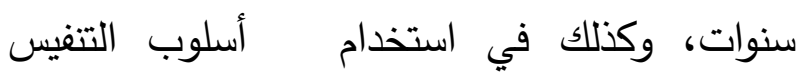
الانفعالي السلبية وذلك لصالح ذوي الخبرة الأقل.

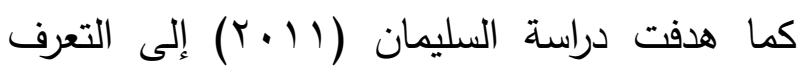

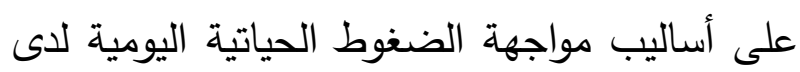
عينة من الطالبات المتقوقات وغير المتفوقات

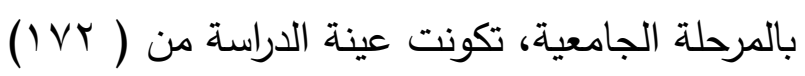

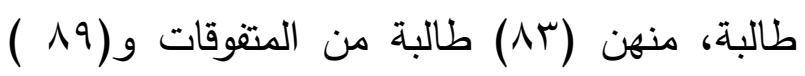
من غير المتفوقات. تم استخدم مقياس أساليب

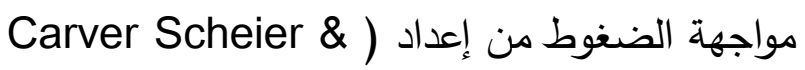
Weintraub,1989) وتطبيقه على البيئة السعودية من قبل الباحثة. أظهرت النتائج وجود فروق ذات دلالة إحصائية بين لئن

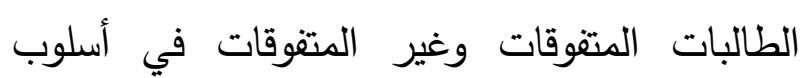
المواجهة بالتخطيط لصالح الطالبات المتفوقات. وكذلك في أساليب المواجهة (الاستسلام والقبول، الإنكار، عدم المبالاة، صرف الانتباه) لصالح الطالبات غير المتفوقات. - الإنكار،

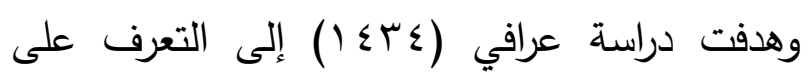
العلاقة بين أساليب مواجهة الضغوط وتأكيد الذات،

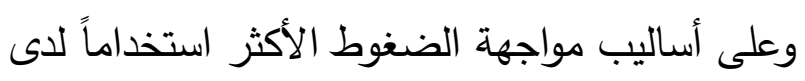

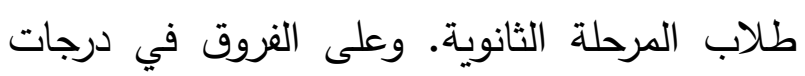
أساليب مواجهة الضغوط بين الأكثر والأقل تأكيداً

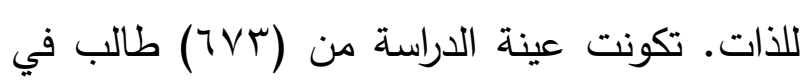

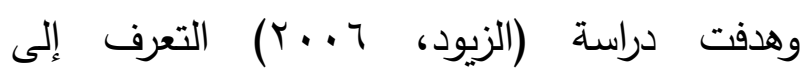
استراتيجيات التعامل مع الضغوط النفسية لدى طلبة جامعة قطر وعلاقتها ببعض المتغيرات. واستخدم الباحث مقياس تحمل الضغوط لجمع البيانات

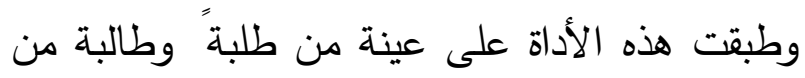
مختلف كليات جامعة قطر شملت (Y^) طالبا. وتوصلت الدراسة إلى أن أكثر الأساليب شيوعا يستخدمها الطلبة هي التفكير الإيجابي واللجوء إلى الى الى الالله، والتتفيس الانفعالي.

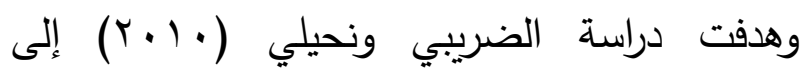
الكثف عن الأساليب التي يتبعها العمال لمواجهة

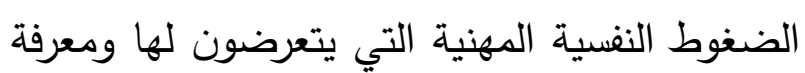
ما إذا كانت هناك فروق دالة إحصائيا في أساليب مواجهة الضغوط تعزى لمتغيرات (سنوات الخبرة، المؤهل العلمي). تكونت عينة الدراسة من (... (Y) عامل، تم اختيارهم بالطريقة العشوائية العرضية. استخدم الباحث مقياس أساليب مواجهة الضغوط بألئه الذي أعده بنفسه وتحقق من صدقه وثباته. أظهرت النتائج أن الأساليب الأكثر استخداما لمواجهة صنه

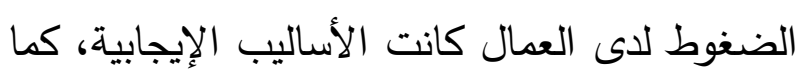
أظهرت وجود فروق ذات دلالة إحصائية في

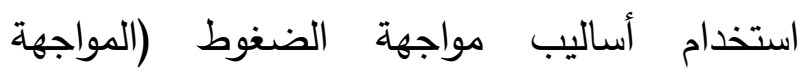
والتحدي واللجوء إلى الدين، إعادة التقييم الإيجابي التئي للمشكلة) وفي الدرجة الكلية للأساليب الإيجابية تعزى إلى المؤهل العلمي(أساسي، ثانوي) لصالح حملة الثهادة الثانوية، وعدم وجود فروق في في لني 
(10.) طالباً من الصف الثالث الثانوي. استخدم الباحث أداتين هما مقياس أساليب مواجهة الضغوط التبان

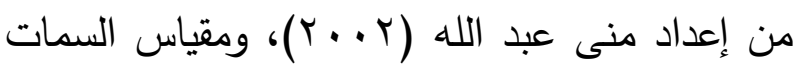

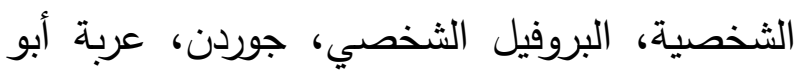

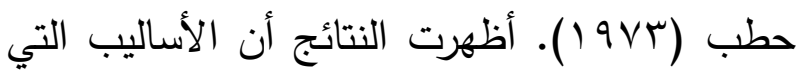
يستخدمها الطلاب في مواجهة الضغوط مرتبة تنازليا هي الالتجاء إلى الله، المواجهة، ضبط ضواهُ الذات، التحليل المنطقي، التركيز على الحل، البحث عن المعلومات، الدعابة، الاسترخاء، الانفصال الذهني،

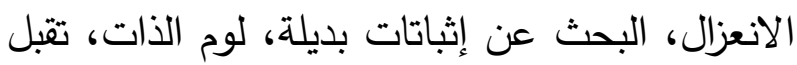

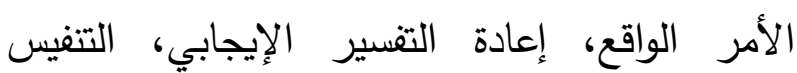

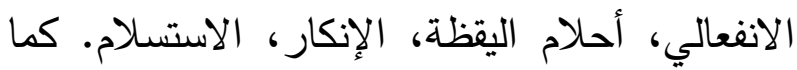
أظهرت النتائج وجود علاقة ارتباطية موجبة بين بعض أساليب مقياس الضغوط ودرجاتهم على وجى السمات الثخصية، وأظهرت وجود فروق في درجات الطلاب بأسلوب المواجهة والتنفيس الانفعالي وتأكيد الذات والدابة ترجع إلى متغير الصف الدراسي لصالح الصف الثالث الثانوي.

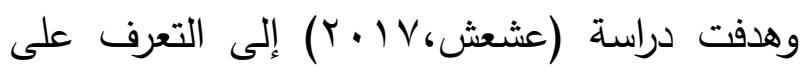
أساليب مواجهة الضغوط النفسية وعلاقتها بالتفاؤل للى عينة من طلاب جامعة بور سعيد في كليتي

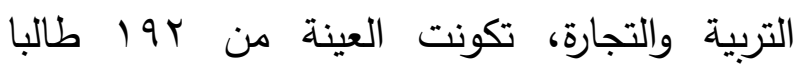
وطالبة، واستخدمت الباحثة مقياس أساليب التعامل مع الضغوط النفسية من إعدادها، وبينت النتائج وجود فروق بين متوسطي درجات طلبة التخصصات الأدبية والتخصصات العلمية في أساليب المواجهة
المرحلة الثانوية، استخدم الباحث أداتين الأولى لقياس أساليب مواجهة الضغوط، والثانية لقياس التراسل السلوك التوكيدي. أظهرت نتائج الدراسة وجود علاقة

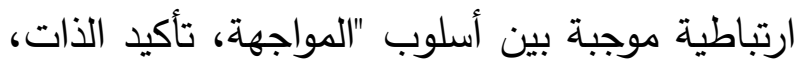

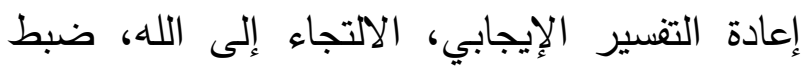

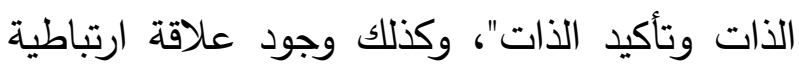

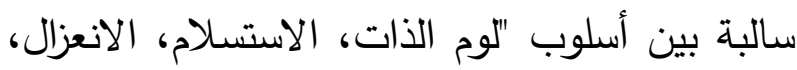

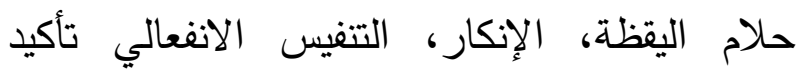

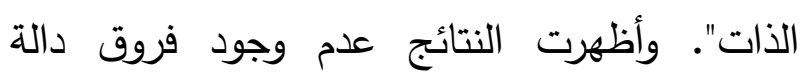

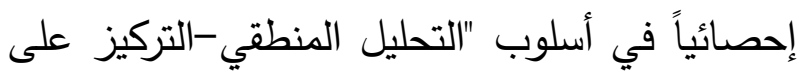
الحل-البحث عن المعلومات-تحمل المسؤولية-تقبل الأمر الواقع-إعادة التقسير الايجابي-الاسترخاء والانفصال الذهني-الدعابة البحث عن إثابات بديلة

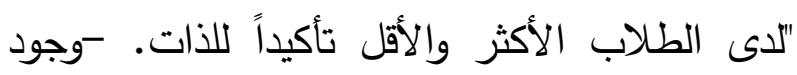
فروق دالة إحصائياً في أسلوب "المواجهة وتأكيد الذات-ضبط الذات-لوم الذات-الالتجاء إلى الله فئه الاستسلام-الانعزال-أحلام اليقظة-الإنكار -التتفيس الانفعالي "لدى الطلاب الأكثر والأقل تأكيداً للذات.

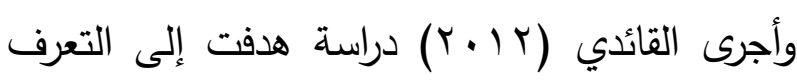
إلى أساليب مواجهة الضغوط، ومعرفة العلاقة بين أساليب مواجهة الضغوط والسمات الثخصية، مواجهة والتحقق من وجود فروق في كل من أساليب مواجهة

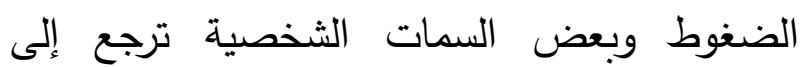

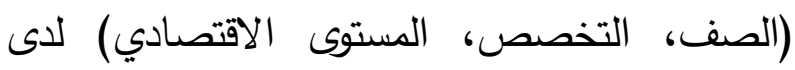
طلاب المرحلة الثانوية في جدة. تكونت عينة

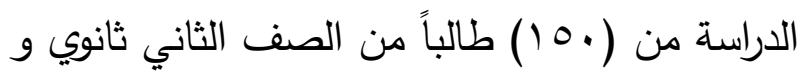


الاجتماعية). وهذه السمات مستقلة نسبيا، وذات أهمية سيكولوجية، وهذه السمات هي: - السيطرة وتعني الاقراد المسيطرون لغوياً، والذين وهنداه

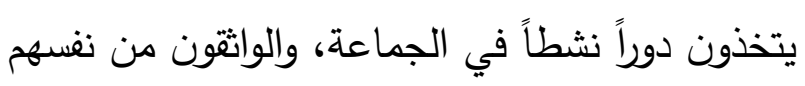

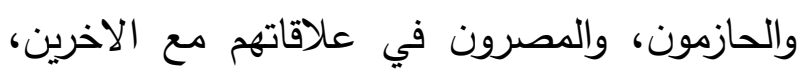

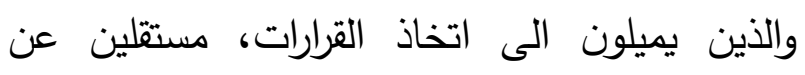
غيرهم. r - تحمل المسؤولية: وتعني الافراد الذين لديهم القدرة على المثابرة والاستمرار في أي عمل يكلفون باه، ويمكن الاعتماد عليهم. r- الاتزان الانفعالي: وتعني الاعني الافراد المتزمتون

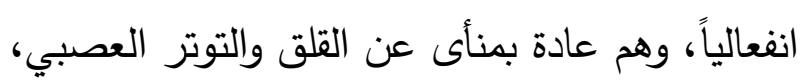

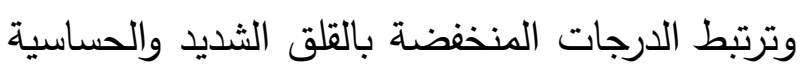
الزائدة والعصبية، وعدم تحمل الإحباط. ع - القابلية الاجتماعية: وتعني الافراد الاجتماعيون الذين يندمجون مع المجتمع ولديهم رغبة لرخالطة الناس، والعمل معهم، ويرغبون في التجمعات. (جابر

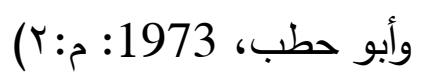
تكون المقياس من 10 فقرة في صورته النهائية بعد إجراء التعديل على فقرات المقياس السابق، وتعديل درجات المقياس والجدول (1) يبين الأبعاد في لئي مقياس السمات الثخصية والفقرات التي تتنمي لكل
الإقدامية عند مستوى دلالة، وأظهرت وجود علاقة ارتباطية موجبة دالة إحصائيا بين طلبة التخصصات الأدبية على بعد أساليب المواجهة الإحجامية وبعد دإلية لئل التشاؤم. تصميم ومنهجية البحث تم استخدام المنهج الوصفي الارتباطي حيث أنهاته لهند ملائم لموضوع وأهداف البحث. مجتمع الدراسة: تكون مجتمع الدراسة من جميع طالبات كلية التربية في جامعة حائل. عينة الدراسة: تم اختيار عينة عشوائية مكونة من . .. ب طالبة من كلية التربية في جامعة حائل. أدوات الدراسة: - تم تصميم أداتين إحداهما لقياس السمات الثخصية، والأخرى لقياس أساليب مواجهة الضغوط إحل وتم احتساب الخصائص السيكومترية لها. أولا: مقياس السمات الثخصية: قامت الباحثة بتطوير مقياس السمات الثخصية بالإفادة من المقياس الذي استخدمته الباحثة نوال

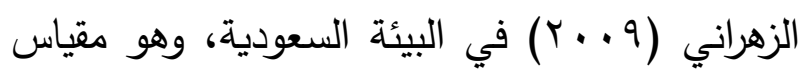
جوردن وعربة أبو حطب (19Vץ ())، تقنين آمال

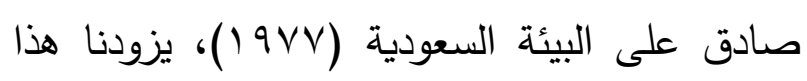
المقياس بقياس أربع سمات للشخصية لها أهمية في

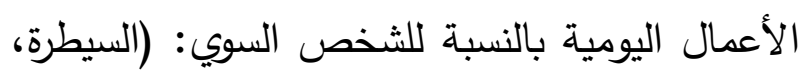
وتحمل المسؤولية، والاتزان الانفعالي و والقابلية 


\begin{tabular}{|c|c|c|}
\hline الفقرات السلبية & 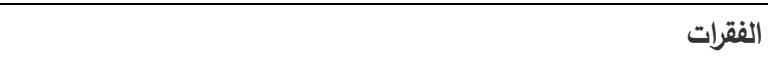 & أساليب مواجهة الضغوط وفقرات \\
\hline$\leq V-0$. & 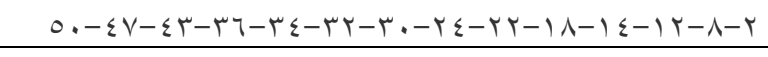 & الاتزان \\
\hline$r \Lambda-r \mu-\varepsilon \varepsilon-0 \leqslant$ & $0 \leqslant-\varepsilon \varepsilon-r r-r \lambda-0 \eta-00-0 r-01-\sum q-r q-r 1-10-11$ & تحمل \\
\hline$r_{0}-\varepsilon r$ & $0 Y-\varepsilon r-r_{0}-\varepsilon 0-r q-r V-r V-r r-19-17-9-V-\varepsilon$ & القابلية \\
\hline$r-r_{\cdot}-\varepsilon_{\cdot}$ & $\varepsilon \cdot-\varepsilon \lambda-\varepsilon \neg-r \Lambda-r \cdot-\varepsilon 1-r_{0}-r|-r q-| \gamma-\mid r-1,-r-0-1$ & السيطرة \\
\hline
\end{tabular}

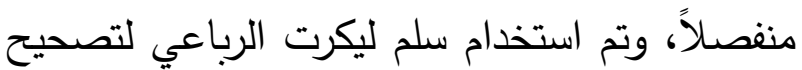
طريقة تصحيح المقياس: أدوات الدراسة، بإعطاء كل فقرة من فقراته درجة تم تصحيح المقاييس الفرعية الاربعة (مقياس السيطرة، مقياس تحمل المسؤولية، مقياس الاتزان واحدة من بين درجاته الأربع(غالبا، أحيانا، نادرا، الانفعالي، مقياس القابلية الاجتماعية) تصحيحاً أبدا)، وهي تمثل رقمياً (ع، ب، ب، ( ) على الترتيب. المعيار الإحصائي:

$$
\begin{aligned}
& \text { من } 1.00 \text { - } 2.00 \text { مستوى متدني } \\
& \text { من } 2.01 \text { - } 3.00 \text { مستوى متوسط } \\
& \text { من } 3.01 \text { - } 4.00 \text { مستوى مرتفع }
\end{aligned}
$$

وقد تم احتساب المقياس من خلال استخدام المعادلة التالية:

الحد الأعلى للمقياس (ع) - الحد الأدنى للمقياس (1)

عدد الفئات المطلوبة (r)

צ-

بعض الفقرات وحذف فقرات أخرى، وتكون المقياس في صورته النهائية من ثبات مقياس السمات الشخصية لاى طالبات جامعة حائل للتأكد من ثبات الأداة، تم حساب الاتساق الداخلي على عينة استطلاعية من خارج عينة الدراسة عددها ( • (ץ) حسب معادلة كرونباخ ألفا، والجدول (r) أدناه
صدق مقياس السمات الشخصية: تم عرض المقياس على سبعة من أعضاء هيئة التدريس من قسم علم النفس بكلية التربية بجامعة حائل لتحكيمه ومدى مناسبة عباراته لثقافة المجتمع السعودي، وكان الاتفاق بين الأعضاء بنسبة (\%^•) المواجهة الضغوط في هذه الدراسة. وكذلك تم تعديل 
يبين هذه المعاملات، واعتبرت هذه النسب مناسبة لغايات هذه الدراسة. جدول (r) معامل الاتساق الاخلي كرونباخ الفا

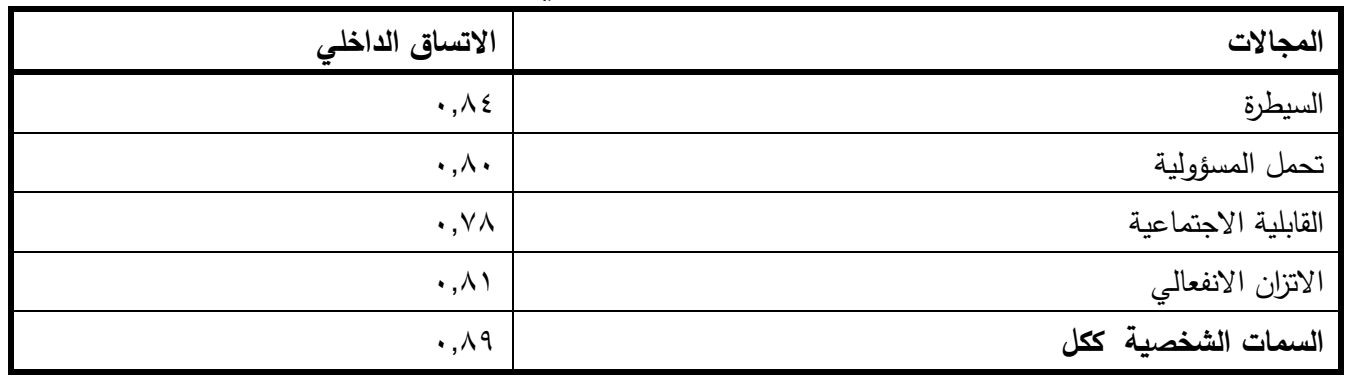

أسلوباً لمواجهة الضغوط، بحيث يشتمل كل أسلوب على ؛ عبارات، وبصف كل أسلوب منها نمط من الأساليب التي بتبعها الأفراد في مواجهة الضغوط التي تعترضههم وتتدرج الدرجات من 1 - ــ درجات على التوالي للخيارات (أبداً، نادراً، أحياناً، غالباً). ولا توجد عبارات عكسية أو سالبة، وتتراوح درجة كل فرد على كل أسلوب بين (ع - 1 ( 1 درجة)؛ والدرجة المنخفضة على كل أسلوب تعني استخدام منخفض لأسلوب مواجهة الضغوط والمرتفعة تعني استخدام مرتفع لأسلوب مواجهة الضغوط. والجدول (r) يبين هذه الأساليب كما وردت في القائمة بصورتها النهائية

ثانيا: مقياس أساليب مواجهة الضغوط: تعريب

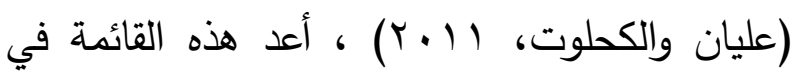

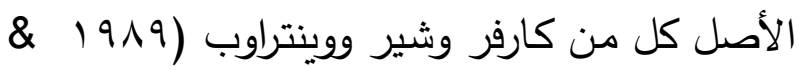
(Scheier, Carver Weintraub النفس من جامعة ميامي Miami بالولايات المتحدة الأمريكية، والصيغة الأصلية لقائمة أساليب مواجهة الضغوط Inventory Cope تتكون من • ج عبارة موزعة على 10 أسلوب لمواجهـة ضـغوط الحياة، وتم حذف الأسـلوب الخـاص باسـتخدام الكحـول والمنبهات Use Substance) بناء على آراء المحكمين، و كونـه لا يتفق مع الدين الإسـلامي والعادات والتقاليد في المجتمعات العربية، وبذلك الك تصبح القائمسة في صورتها النهائية مكونـة من ع 1

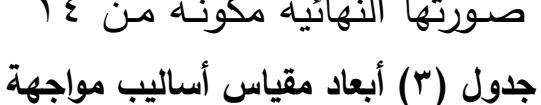

\begin{tabular}{|c|c|c|c|c|}
\hline 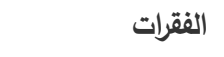 & 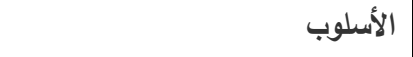 & 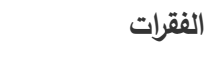 & \multicolumn{2}{|c|}{ أساليب مواجهة الضغوط وفقرات كل } \\
\hline$\sum V-r r-19-\Lambda$ & 1- السخربة & $00-r 0-r V-1$ & إعادة التقييم & -0 \\
\hline$\varepsilon \Lambda-\varepsilon r-r r-q$ & 9- الانسحاب الاجتماعى & $r 9-\varepsilon \cdot-10-r$ & الشرود العقلى - الي & -7 \\
\hline$\leq \neg-r \wedge-r \mid-1$. & • 1-السيطرة على الاعصاب التروي & $\sum r-r q-17-r$ & 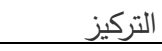 & $-V$ \\
\hline$\sum q-r r-r r-11$ & 11-طلب الدعم العاطفى & $\varepsilon r-r \wedge-1 r-\varepsilon$ & 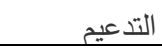 & $-\Lambda$ \\
\hline $0 \cdot-\varepsilon 1-r \cdot-1 r$ & 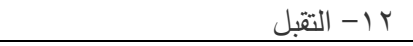 & $0 \leqslant-\varepsilon \leqslant-Y \leqslant-0$ & 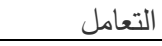 & -9 \\
\hline Or-rד-r.-11 & ب ا - اشغال الذهن بالتتكير & Or-rV-rO-Y & 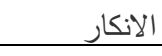 & -1 \\
\hline Or-rı-r.-11 & ع ا- التخطيط & $07-\leqslant 0-1 V-V$ & التكيف & -11 \\
\hline
\end{tabular}

وتم استخدام نفس معيار التصحيح للتصنيف إلى مستويات الذي استخدم في مقياس السمات الشخصية. 
ثبات مقياس أساليب مواجهة الضغوط للتأكد من ثبات الأداة، تم حساب الاتساق مواجنه الداخلي على عينة استطلاعية من خارج عينة الدراسة عددها

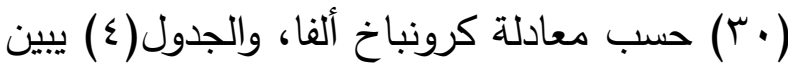
هذه المعاملات، واعتبرت هذه النسب مناسبة لغايات

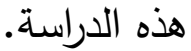

صدق مقياس أساليب مواجهة الضغوط : تم عرض المقياس على سبعة من أعضاء هيئة

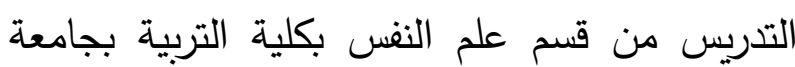
حائل لتحكيمه ومدى مناسبة عباراته لثقافة المجتمع لنابه

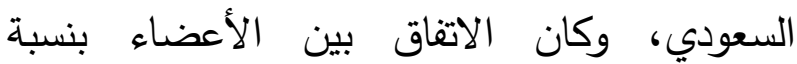
(\%^^) المواجهة الضغوط في هذه الدراسة.

جدول (؛ ) معامل الاتساق الاخلي كرونباخ الفا

\begin{tabular}{|c|c|}
\hline | الاتساق الداخلي & 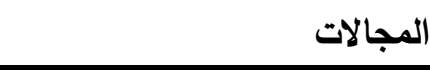 \\
\hline$\cdot, \times 9$ & إعادة التقييم الإيجابي \\
\hline$\cdot, \Delta Y$ & الشرود العقلي \\
\hline$\cdot, V \varepsilon$ & التركيز والتتريغ الانفعالي \\
\hline$\cdot, \mathrm{V4}$ & التدعيم الاجتماعي \\
\hline$\cdot, \mathrm{VT}$ & التعامل الفعال النشط \\
\hline$\cdot$, vo & الإنكار \\
\hline$\cdot, \wedge \cdot$ & التكيف الروحاني لديني \\
\hline$\cdot, \Delta r$ & 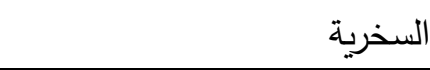 \\
\hline$\cdot, \wedge 1$ & الانسحاب السلوكي \\
\hline$\cdot, \vee \vee$ & السيطرة على الأعصاب "التروي" \\
\hline$\cdot, \lambda r$ & طلب الدعم العاطفي \\
\hline$\cdot$, vo & 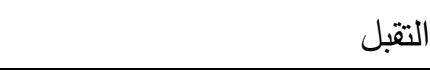 \\
\hline$\cdot, \mathrm{VV}$ & إشغال الذهن بالتفكير \\
\hline$\cdot, \wedge 1$ & التخطيط \\
\hline$\cdot, \wedge \Lambda$ & أساليب مواجهة الضغوط ككل \\
\hline
\end{tabular}

نتائج الاراسة ومناقشتها: السؤال الاول: ما مستوى سمات الثخصية لاى طالبات جامعة حائل؟ 
للإجابة عن هذا السؤال تم استخراج المتوسطات الحسابية والانحرافات المعيارية لمستوى سمات الشخصية لاى طالبات جامعة حائل مرتبة تنازلياً حسب المتوسطات الحسابية والجدول (0) يوضح ذلاج الك. جدول (0) المتوسطات الحسابية والانحرافات المعيارية لمستوى سمات الثخصية لاى طالبات جامعة حائل

\begin{tabular}{|c|c|c|c|c|c|}
\hline المستوى & الانعراف & الحستوسطي & المجال & الرقم & الرتبة \\
\hline متوسط & .523 & 2.66 & الاتزان الانفعالي & $\varepsilon$ & 1 \\
\hline متوسط & .685 & 2.59 & تحمل المسؤولية & r & r \\
\hline متوسط & .597 & 2.58 & القابلية الاجتماعية & $r$ & $r$ \\
\hline \multirow[t]{2}{*}{ متوسط } & .614 & 2.57 & السيطرة & 1 & $\varepsilon$ \\
\hline & .558 & 2.58 & السمات الثخصية ككل & & \\
\hline
\end{tabular}

التقاعل الاجتماعي مما يزيد من مستوى سمة القابلية

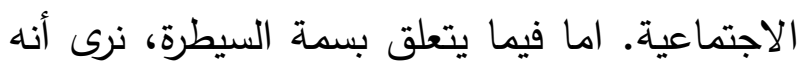
بسب اكتساب الطالبة مجموعة جديدة من الخبرات

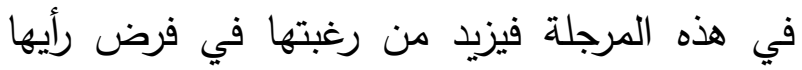

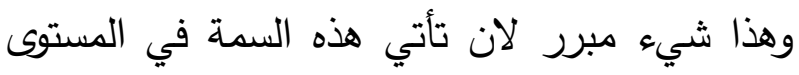

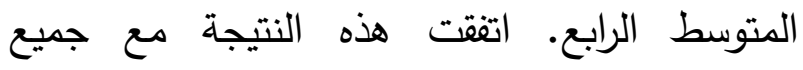
نظريات الشخصية التي تئكد على وجود السمات الشخصية لدى جميع الأفراد بنسب متفاوتة، وهذا يتقق مع مبدأ الفروق الفردية، ويعود هذا التباين في لني سمات الثخصية لاختلاف العوامل المؤثرة فيهم مثل مئل البيئة والثقافة وأساليب التنشئة الاجتماعية، وهذه لاحئل النتيجة تؤكد على أهمية هذه العوامل في التأثير في السمات الشخصية كما يراه الكثير من العلماء أمثال

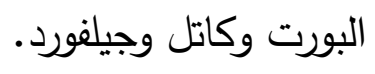

السؤال الثاني: ما مستوى استخدام أساليب مواجهة

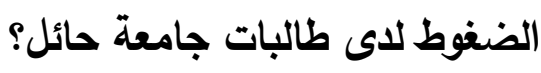

يبين الجدول (0) أن المتوسطات الحسابية قد تراوحت ما بين (2.57-2.66)، حيث جاء الاتزان الانفعالي في المرتبة الأولى بأعلى متوسط حسابي بلغ (2.66)، وجاءت تحمل المسؤولية في المرتبة الثانية بمتوسط حسابي بلغ (r,09)، وجاءت القابلية الاجتماعية في المرتبة الثالثة بمتوسط حسابي بلغ (2.58) بينما جاءت السيطرة في المرتبة الأخيرة وبمتوسط حسابي بلغ (2.57). تبدو هذه النتيجة منطقية ومقبولة لدى الطالبات في هذه المرحلة

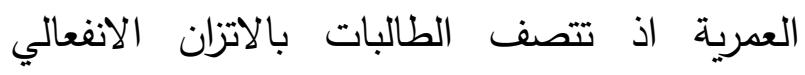
بمستوى متوسط وكذلك فيما يتعلق بسمة تحمل المسؤولية وذلك لان الطالبات تمكن من اجتياز

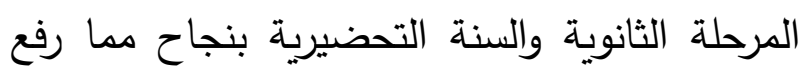
قدرتهن على تحمل المسؤولية وفيما يتعلق بسمة ولهاحس القابلية الاجتماعية جاءت في الترتيب الثالث وبمستوى متوسط أيضا ويمكن تفسيره لان الطالبات في البيئة الجامعية يكتسبن العديد من مهارات 
للإجابة عن هذا السؤال تم استخراج المتوسطات مرتبة تنازلياً حسب المتوسطات الحسابية، والجدول الحسابية والانحرافات المعيارية لمستوى استخدام (ד) يوضح ذلك. أساليب مواجهة الضغوط لدى طالبات جامعة حائل جدول (†) المتوسطات الحسابية والانحرافات المعيارية لمستوى استخدام أساليب مواجهة الضغوط لاى طالبات جامعة حائل

\begin{tabular}{|c|c|c|c|c|c|}
\hline المستوى & الانحراف & المتوسط & المجال & الرقم & الرتبة \\
\hline 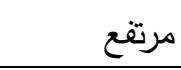 & .618 & 3.01 & التركيز والتثريغ الانفعالي & r & 1 \\
\hline متوسط & .660 & 2.95 & التكيف الروحاني لديني & v & r \\
\hline متوسط & .599 & 2.92 & إشغال الذهن بالتفكير & Tr & r \\
\hline متوسط & .707 & 2.91 & التدعيم الاجتماعي & $\varepsilon$ & $\varepsilon$ \\
\hline متوسط & .653 & 2.90 & السخرية & $\wedge$ & 0 \\
\hline متوسط & .719 & 2.90 & طلب الدعم العاطفي & 11 & 0 \\
\hline متوسط & .695 & 2.88 & التعامل الفعال النشط & 0 & $\checkmark$ \\
\hline متوسط & .612 & 2.88 & الإنكار & 7 & $\checkmark$ \\
\hline متوسط & .677 & 2.87 & السيطرة على الأعصاب "التروي" & 1. & 9 \\
\hline متوسط & .689 & 2.85 & الاتسحاب السلوكي & 9 & 1. \\
\hline متوسط & .737 & 2.84 & الشرود العقلي & r & 11 \\
\hline متوسط & .671 & 2.83 & التقبل & ir & ir \\
\hline متوسط & .641 & 2.81 & إعادة التقييم الإيجابي & 1 & ir \\
\hline \multirow[t]{2}{*}{ متوسط } & .670 & 2.81 & التخطيط & $1 \leq$ & س \\
\hline & .567 & 2.88 & أساليب مواجهة الضغوط ككل & & \\
\hline
\end{tabular}

يبين الجدول (0) أن المتوسطات الحسابية تراوحت الثالثة بمتوسط حسابي بلغ (2.92)، وجاء التدعيم بين (2.81-3.01)، حيث جاء التركيز والتثريغ الاجتماعي في المرتبة الرابعة بمتوسط حسابي بلغ الانفعالي في المرتبة الأولى بأعلى متوسط حسابي (2.91)، وجاءت السخرية في المرتبة الخامسة بلغ (3.01) وهو مستوى مرتفع، وجاءت بقية بمتوسط حسابي بلغ (2.90)، بينما جاء كل من الفقرات بمستوى متوسط، إذ جاء التكيف الروحاني إعادة التقييم الإيجابي، والتخطيط في المرتبة الأخيرة لايني في المرتبة الثانية بمتوسط حسابي بلغ وبمتوسط حسابي بلغ (2.81). (2.95)، وجاء إشغال الذهن بالتفكير في المرتبة 


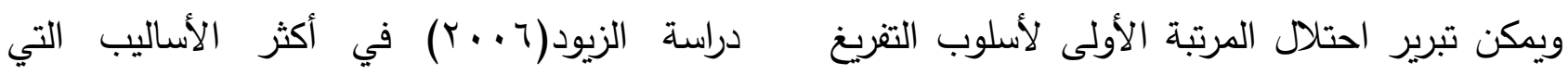

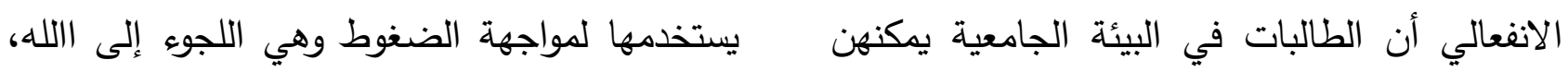

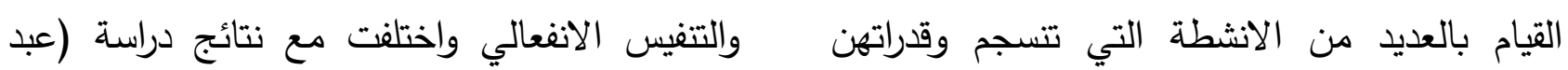

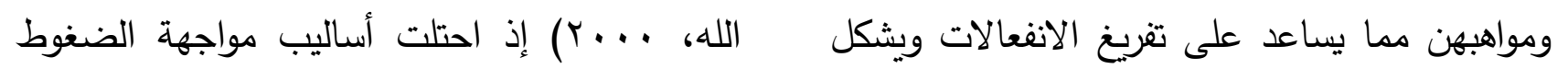

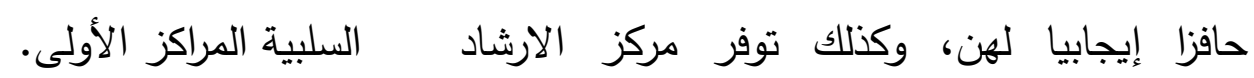
والتوجيه في الجامعة والذي يهتم بمشاكل الطالبات السؤال الثالث: ما العلاقة بين السمات الثخات الثخصية

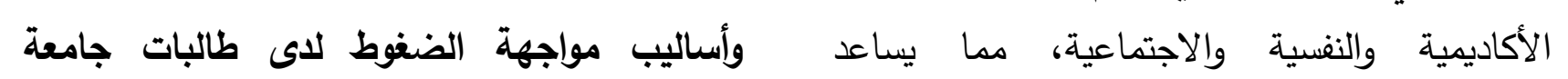

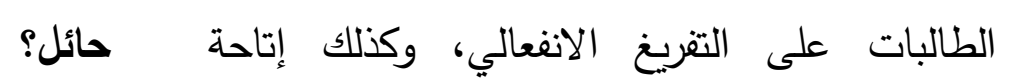

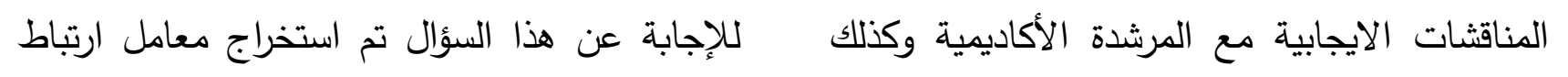

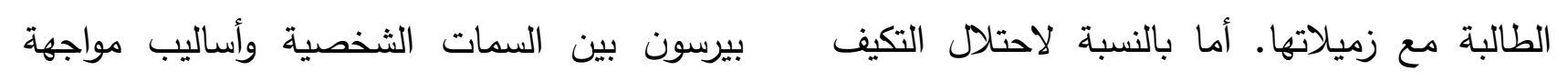

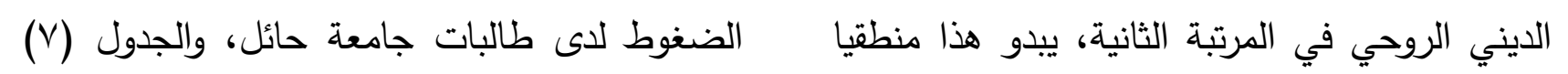

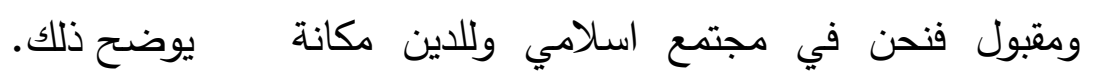

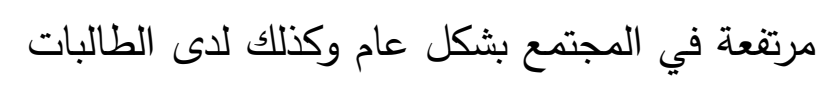
مما يجعل لتعاليم الدين والاعتماد عليه الأثر الهام

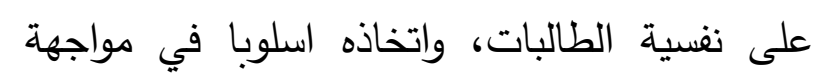
العديد من الضغوطات.

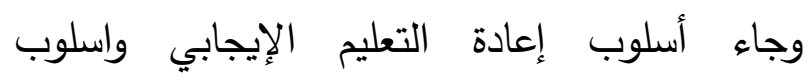
التخطيط في المستوى الأخير وذلك ربما بسبب التباء انشغال الطالبات بالعديد من الأمور الدراسية والواجبات والانشطة مما يجعل استخدامها للتخطيط بلتطال بشكل متوسط وأقل من الأساليب الأخرى. اتفقت هذه

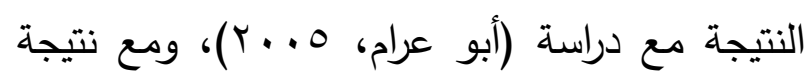

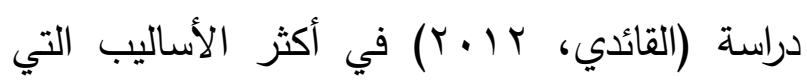
استخدمها الطلاب وهي اللجوء إلى الله، وكذلك الكي

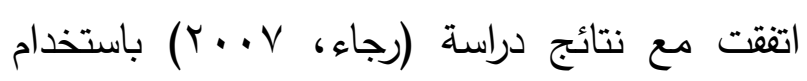

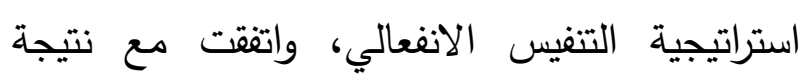


جدول (V) معامل ارتباط بيرسون للعلاقة بين السمات الثخصية وأساليب مواجهة الضغوط لاى طالبات جامعة حائل

\begin{tabular}{|c|c|c|c|c|c|}
\hline الاتزان الانفعالي & الاجتابلية & تحمل المسؤولية & السيطرة & & \\
\hline $.722(* *)$ & $.668(* *)$ & $.690(* *)$ & $.583(* *)$ & معامل الارتباط ر & إعادة التقييم الإيجابي \\
\hline .000 & .000 & .000 & .000 & الدلالة الإحصائية & \\
\hline 300 & 300 & 300 & 300 & 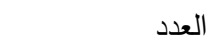 & \\
\hline $.835(* *)$ & $.755(* *)$ & $.850(* *)$ & $.729(* *)$ & معامل الارتباطر & الثرود العقلي \\
\hline .000 & .000 & .000 & .000 & الدلالة الإحصائية & \\
\hline 300 & 300 & 300 & 300 & العدد & \\
\hline $.756(* *)$ & $.656(* *)$ & $.743(* *)$ & $.630(* *)$ & معامل الارتباط ر & التركيز والتفريغ الانفعالي \\
\hline .000 & .000 & .000 & .000 & الدلالة الإحصائية & \\
\hline 300 & 300 & 300 & 300 & العدد العد & \\
\hline $.731(* *)$ & $.792(* *)$ & $.709(* *)$ & $.658(* *)$ & معامل الارتباط ر & التدعيم الاجتماعي \\
\hline .000 & .000 & .000 & .000 & الدلالة الإحصائية & \\
\hline 300 & 300 & 300 & 300 & 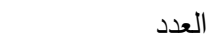 & \\
\hline $.822(* *)$ & $.688(* *)$ & $.828(* *)$ & $.667(* *)$ & معامل الارتباط ر & التعامل الفعال النشط \\
\hline .000 & .000 & .000 & .000 & الدلالة الإحصائية & \\
\hline 300 & 300 & 300 & 300 & العدد العد & \\
\hline $.627(* *)$ & $.503(* *)$ & $.496(* *)$ & $.422(* *)$ & معامل الارتباطر ر & الإنكار \\
\hline .000 & .000 & .000 & .000 & الدلالة الإحصائية & \\
\hline 300 & 300 & 300 & 300 & العدد العد & \\
\hline $.729(* *)$ & $.668(* *)$ & $.695(* *)$ & $.783(* *)$ & معامل الارتباط ر & التكيف الروحاني لايني \\
\hline .000 & .000 & .000 & .000 & الدلالة الإحصائية & \\
\hline 300 & 300 & 300 & 300 & 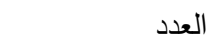 & \\
\hline $.847(* *)$ & $.729(* *)$ & $.815(* *)$ & $.759(* *)$ & معامل الارتباط ر & السخرية \\
\hline .000 & .000 & .000 & .000 & الدلالة الإحصائية & \\
\hline 300 & 300 & 300 & 300 & 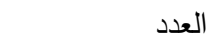 & \\
\hline $.767(* *)$ & $.696(* *)$ & $.737(* *)$ & $.753(* *)$ & معامل الارتباط ر & الانسحاب السلوكي \\
\hline .000 & .000 & .000 & .000 & الدلالة الإحصائية & \\
\hline 300 & 300 & 300 & 300 & 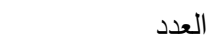 & \\
\hline $.758(* *)$ & $.712(* *)$ & $.739(* *)$ & $.730(* *)$ & معامل الارتباط ر & السيطرة على الأعصاب "التروي" \\
\hline .000 & .000 & .000 & .000 & الدلالة الإحصائية & \\
\hline 300 & 300 & 300 & 300 & العدد & \\
\hline $.809(* *)$ & $.797(* *)$ & $.797(* *)$ & $.674(* *)$ & معامل الارتباط ر & 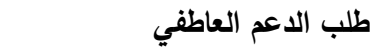 \\
\hline
\end{tabular}




\begin{tabular}{|c|c|c|c|c|c|}
\hline .000 & .000 & .000 & .000 & الدلالة الإحصائية & \\
\hline 300 & 300 & 300 & 300 & العدد - العد & \\
\hline $.808(* *)$ & $.759(* *)$ & $.825(* *)$ & $.715(* *)$ & معامل الارتباط ر & التقبل \\
\hline .000 & .000 & .000 & .000 & الدلالة الإحصائية & \\
\hline 300 & 300 & 300 & 300 & العدد & \\
\hline $.803(* *)$ & $.646(* *)$ & $.682(* *)$ & $.677(* *)$ & معامل الارتباطر & إشغال الذهن بالتفكير \\
\hline .000 & .000 & .000 & .000 & الدلالة الإحصائية & \\
\hline 300 & 300 & 300 & 300 & العدد & \\
\hline $.841(* *)$ & $.732(* *)$ & $.801\left({ }^{* *}\right)$ & $.713\left({ }^{* *}\right)$ & معامل الارتباطر & التخطيط \\
\hline .000 & .000 & .000 & .000 & الدلالة الإحصائية & \\
\hline 300 & 300 & 300 & 300 & العدد & \\
\hline
\end{tabular}

وتقديم دورات ورش عمل بشكل مستمر في تطوير الذات وتتمية تلك المهارات. - الاهتمام بإكساب الطالب مهارات حياتية وتضمينها في مقرر يدرس ضمن الخطة الدراسية للكلية تمكنه من مواجهة الضغوط النغسية. - إجراء المزيد من الدراسات على مجتمع الدراسة ومجتمعات أخرى، وإجراء مقارنات مع الدراستة الحالية. - الإفادة من الدراسات والخبرات الدحلية والعالمية التي أجريت في هذا الدجال، لمواجهة الضغوط التي التي

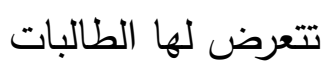
قائمة المراجع:

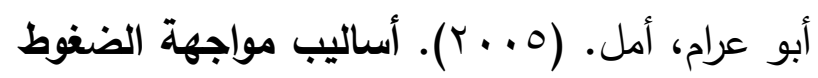
وعلاقتها ببعض سمات الثخصية. رسالة دكتوراة. معهد الدراسات العليا للطفولة، قسم الدراسات النفسية لاجتماعية،
يتبين من الجدول (آ) وجود علاقة ايجابية دالة إحصائيا بين السمات الثخصية وأساليب مواجهة الضغوط لاى طالبات جامعة حائل. وهذه نتيجة منطقية ومقبولة اذ كلما ارتقت السمات الثخصية الايجابية سيشكل هذا دافعا للتعامل بشكل ايجابي

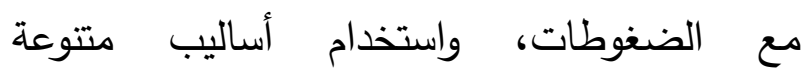

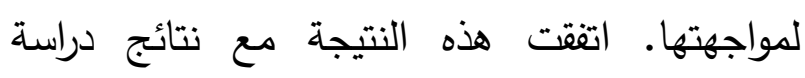

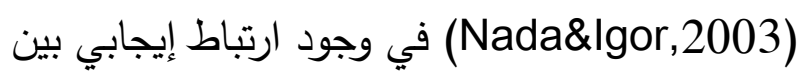
الانبساط وأسلوب مواجهة الانفعال، واتنقت كذلك مع إنابك

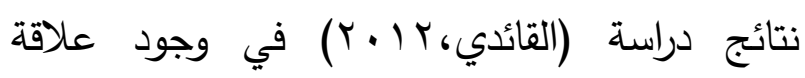
ارتباطية بين السمات الثخصية وأساليب مواجهة الضغوط. التوصيات: - عدم إغفال موضوع الضغوط النفسية وأساليب مواجهتها وعلاقتها بالسمات الثخصية، 
وغير المتفوقات بالمرحلة الجامعية.

المؤتمر العلمي الثاني لقسم الصحة

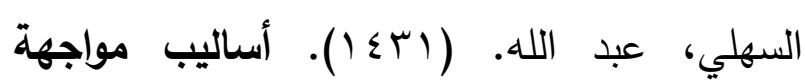
الضغوط النفسية لاى الثباب من

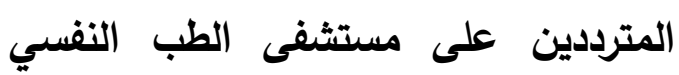

بالمدينة المنورة وغير المرضس. رسالة دكتوراه غير منشورة، قسم علم النفس، كلية

$$
\text { التربية، جامعة أم القرى: مكة غلئو }
$$

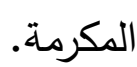

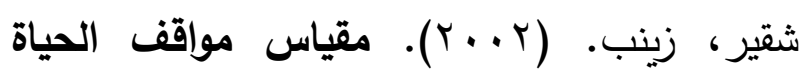
الضاغطة في البيئة العربية. مكتبة النهضة المصرية، القاهرة.

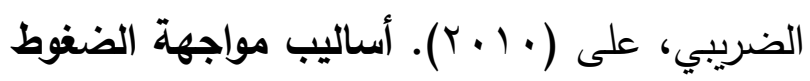
النفية والمهنية وعلاقتها ببعض المض

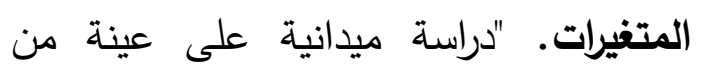

$$
\text { العاملين بمصنع زجاج القدم بدمشق". }
$$

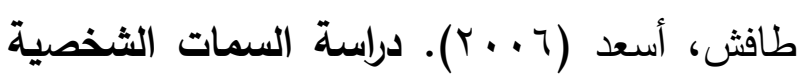

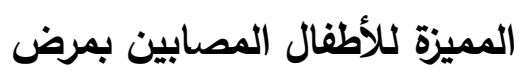
التلاسيميا وعلاقتها ببعض المتغيرات. رسالة جامعية غير منشورة، الجامعة الإسلامية، غزة، فلسطين.

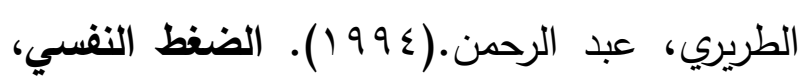
مفهومه، تثخيص، طرق علاجه

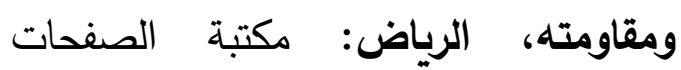
الذهبية.
جامعة عين شمس. القاهرة.

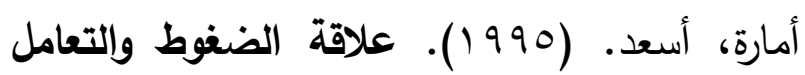
معها بالخصائص العصابية لاى طلبة الجامعة. رسالة دكتوراة غير منشورة، لابها الجامعة المستتصرية، بغداد.

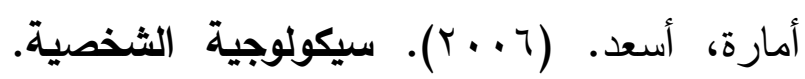

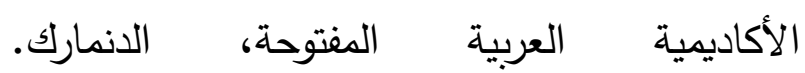

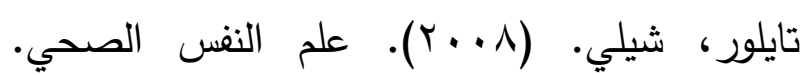
(ترجمة: وسام بريك، وفوزي طعيمة)، دار

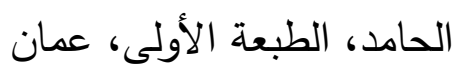

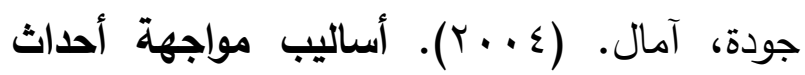
الحياة الضاغطة وعلاقتها بالصحة النفسية لاى عينة من طلاب وطالبات جامعة الأقصى. بحث مقدم للمؤتمر

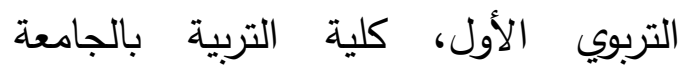
الإسلامية، فلسطين.

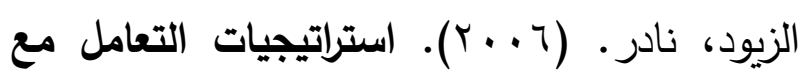
الضغوط النفسية لاى طلبة جامعة قطر وعلاقتها ببعض التغيرات. مكتب جامعه

$$
\text { التربية العربي لدول الخليج، العدد } 99 .
$$

السليمان، نورة. (11) (1). أساليب مواجهة الضغوط لاى عينة من الطالبات المتفوقات 
عشعش، سارة. (Y V V V). أساليب مواجهة الضغوط النفسية وعلاقتها بالتفاؤل لاى الى

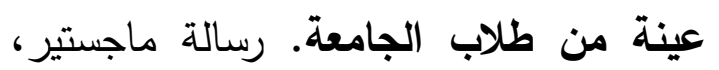

$$
\text { مجلة كلية التربية، بور سعيد. }
$$

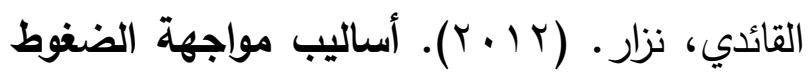

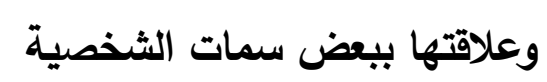

لاى طلاب المرحلة الثانوية بمحافظة جدة.

$$
\text { رسالة ماجستير غير منشورة، قسم علم }
$$$$
\text { النفس، كلية التربية، جامعة أم القرى. }
$$

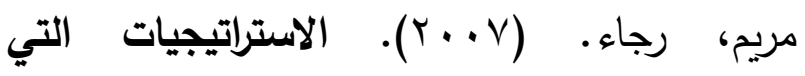
يستخدمها الطلبة للتعامل مع الضغوط

النفسية في كلية التربية بجامعة دمثق.

$$
\text { مجلة اتحاد الجامعات العربية للتربية }
$$

\section{المراجع الأجنبية:}

Hunt, N, \& Evans, D. (2004). Predicting traumatic stress using emotional intelligence. Behaviour Research and Therapy, 42(7), 791-798

Igor Kardum, Nada Karpic (2003). Personality Traits, Stressful Life events and coping styles in early adolescence. Journal Article. Vol (30)
عبود، هيام. (•(ץ). بعض السمات الثخصية لاى الممارسات وغير الممارسات للأنشطة الرياضية. بحث منشور ، مركز الميلمات أبحاث الطفولة والأمومة، جامعة ديالى ليطي

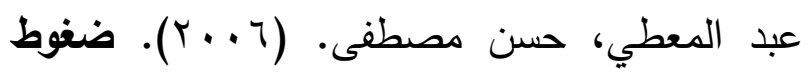
الحياة وأساليب مواجهتها، زهراء b

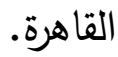

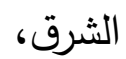

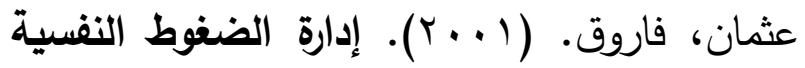

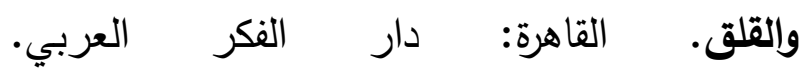
عرافي، أحمد. (ع آ؟ ()). أساليب مواجهة الضغوط وعلاقتها بتأكيد الذات لاى طلاب المرحلة الثانوية في محافظة مهر الذهب. رسالة ماجستير غير منشورة، قسم علم النفس، كلية التربية، جامعة أم القرى.

Neala S, Rita S (1996). Dual-Earner Families: The Importance of Work Stress and Family Stress for Psychological Well-Being

Lazarus (R.S) \& Folkman (S) (1984) Pychological Stress and the coping process M.C Graw. Hill New york.

Selye, H (1976), The Stress of life, Mc Craw, Hill book Company, Revised edition, New work. 


\title{
Personal Traits, their Correlation with Methods to Face Stress, among Female Students at the Faculty of Education, University of Hail.
}

\author{
Kawthar Salameh Jubara \\ Assistant professor at Department of psychology \\ Faculty of Education- University of Hail \\ kawsrmgh@hotmail.com
}

\begin{abstract}
College of Education at University of Hail, and the methods to face psychological stress, of coping with their psychological pressures, and to determine the correlation between personality traits and methods of facing psychological stress among those students. The sample consisted of (300) female students who were randomly selected from the Faculty. Two tools were used; one of them was applied to measure several personality traits, the researcher prepared it in light of a previous study

The second tool which was used to detect the methods of facing stress among students was applied in a previous study (Arabization by Alayyan and Kahlout). The validity and reliability of the two tools were calculated. The findings showed that the level of personality traits was moderate, and they were: (emotional balance, shouldering responsibility, social viability and control) respectively.

Furthermore, the results revealed that the students had several attitudes to overcome stress: attentiveness and emotional discharge method came first by high mean, As for the other methods, they were at a moderate level, while positive re-assessment and planning came in the last rank. In addition, there was a positive statistically significant correlation between personal traits and methods of facing stress among students at Hail University. The study recommended not forgetting the issue of psychological stress and methods of coping with it, and paying attention to providing students with life skills that enable them to face psychological pressures.
\end{abstract}

Key words: personal traits, methods of facing stress, attentiveness and emotional discharge.. 